\title{
Early Reminiscences of Railroads
}

JOHN P. VANDER MAAS

Editor's Note: The John P. Vander Maas Collection of Railroadiana is a large and impressive gathering of photographs and other types of source material related to one of America's foremost industries. Included are timetables, train orders, menus, tickets, passes, photographs of locomotives and equipment, postcards, business forms, and much more, all donated by John P. Vander Maas. While an article in the April 1988 issue of Books at Iowa discussed the ever-growing collection itself, the editors asked Mr. Vander Maas to recall some of his memories of railroads. Here, in his own words, are those recollections:

Age 10. 1923. I was already railroad oriented, having spent the six previous summers in a Mississippi River cottage that had nearly in its back yard, the beloved St. Louis to Burlington main line of the Chicago, Burlington \& Quincy Railroad (CB\&Q). My father managed a food processing company that had twenty or so produce-buying stations in northeast Missouri and south central Iowa. At one station in Kahoka, Missouri, twenty-four miles west of Keokuk, Iowa, the manager had acquired a young fox terrier which my father said I could have. He was to be shipped in a crate by Railway Express on the Keokuk \& Western (K \& W) passenger local. (Long ago the $K \& W$ became a part of the Burlington, but to my father's generation it would always be the $K \& W$.) Came then the magic day. I had begun early to plead "Let's get to the station." Thus, we were there ahead of time. I was yet unaware of the delays that were a part of early-day branch-line railroading. Finally that train was in sight and crept to the Union Depot passenger track at Keokuk. The Railway Express car door was open and almost at once the messenger became aware of the 


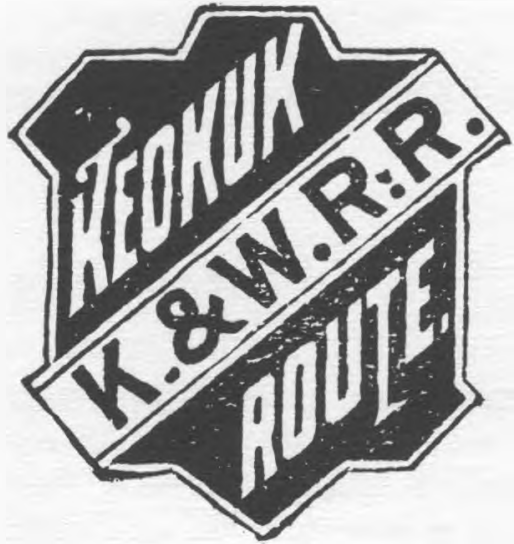

situation and one crated dog was placed in the doorway. There had to be a signature and payment. That I did not witness because I was already reaching in to welcome my dog.

Age 14. 1927. Ten summers already in the family cottage at Sandusky, Iowa, and very near at all times to my two favorites: in front the Mississippi River and in back the St. Louis to

Burlington main line of the $C B \& Q$. My parents announced that a new canoe was to be my birthday gift. Transportation from Old Town, Maine, I soon learned, was to be slow. Shipping was all by railroads then, and in those pre-mega-merger days several different roads would be involved. As was the custom, a copy of the waybill was mailed and when handed to me by my father, he was careful to explain its function. I was fascinated by the initials of the several roads involved and from that developed a life-long liking for the iron pikes. Six days weekly the local freight took the siding at Sandusky so the usual north and south passenger locals could operate on the single track. I had been taught safety by the local freight crews and allowed "the run" of their train. As soon as the bill of lading was handed me I began pestering the local freight train crew with "Do you have a canoe?" Forever for a fourteen-yearold and probably fifteen days from Old Town, Maine. Came then that memorable day when a crew member hollered "We have a canoe for you". They carefully unloaded and toted it to the front yard of the cottage. All laboring males carried sharp pocket knives then so the sisal twine holding the burlap layers was soon off and they carried it out on the family swimming dock and placed it in the big river. 
133-GHIGACo, BURLImeton \& qUIMGY RAILROAD GO.-133 LESS THAN CAR LOAD FREIGHT WAYBILL
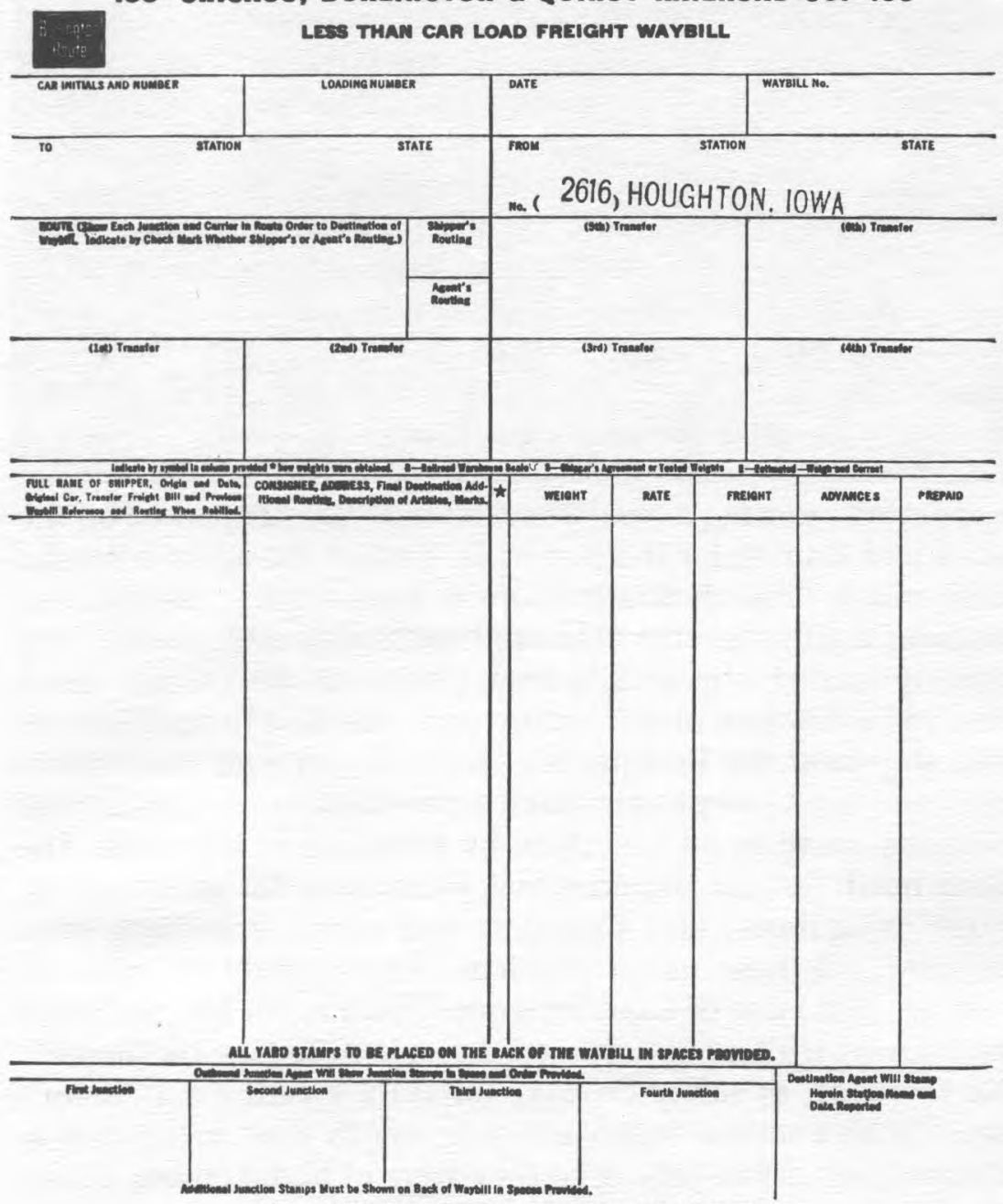

133-CHICACO, BURLINGTON \& QUINCY RAILAOAD CO.-133

Sample waybill 
Age 18. 1931. During my freshman year at Grinnell College, my best friend was Roy Snellman of North Ironwood, Gogebic County, Michigan, and an invitation came for a fishing trip. Many pleasant surprises awaited me. The Upper Peninsula of Michigan was undeveloped then. The family lived above a one-man general store operated by the father who also served as court interpreter being bilingual and thus very popular with his mostly Finnish-immigrant populated trade area. The mother was barely able to converse in English, but blessed with her native Finland baking ability. I soon learned "iltapäiväkahvi" and a table laden with all sorts of home baking was a never-missed daily ritual as was the weekly sauna steam bath. Fly fishing on the Presque Isle River was the objective but no auto roads at all existed then north or northeast of North Ironwood; getting there was easily arranged by the influential father with the nearby railroad agent and a trackman. On the appointed morning a four-wheel section car was parked on the track and waiting for the two of us. I asked the agent what the DSS and A (Duluth South Shore \& Atlantic) represented and without a blink he said "Damn Small Salary and Abuse." We quickly loaded our week's back packs on the section car. I enjoyed every foot of the twenty plus mile ride to Tula, a mere flag stop near the Presque Isle River. Enroute all was wilderness and trees except now and then evidence of timber cutting, but very small as all was done by hand axe at that time. The walk north to Lake Superior was memorable for good fishing, huge mosquitoes, and shoulders that ached from back strap tugging. All these minor problems were quickly set aside by just my first view of Lake Superior. There again Mr. Snellman had scored with a pre-arranged motor boat to take us "home". No toy boat, as safety on Lake Superior meant a fisherman's scow, with a several-man crew. Apparently their occupation in Finland was ocean fishing so they were at home on our inland sea. 


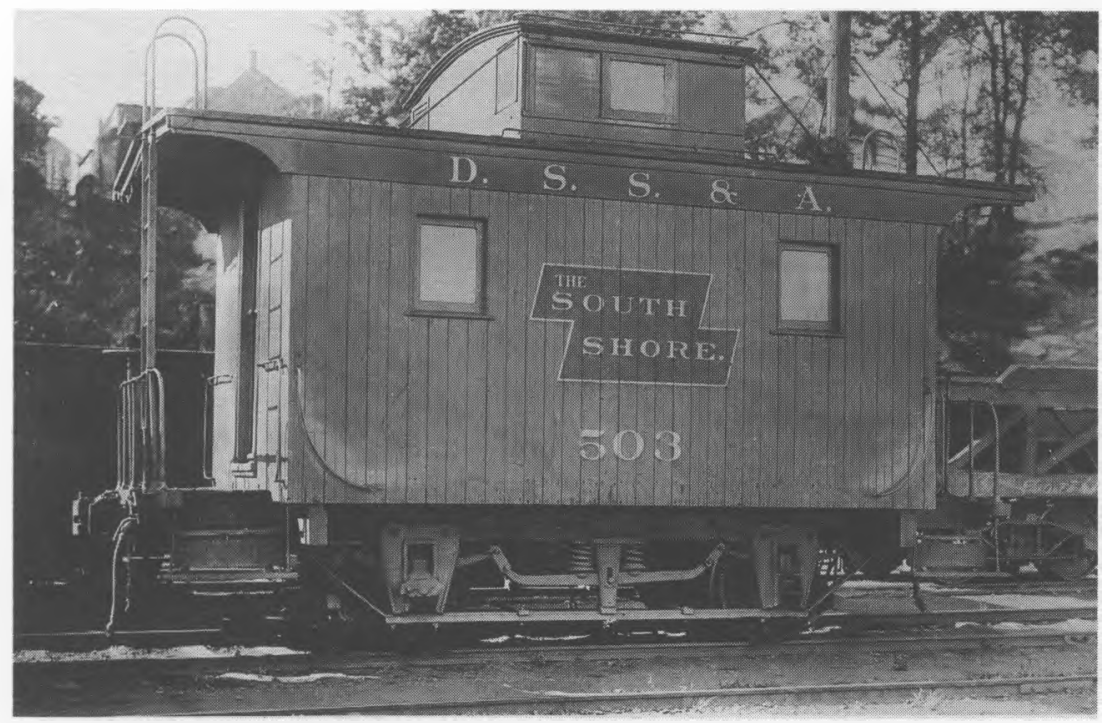

Duluth South Shore \& Atlantic caboose, 1911.

Editor's Note: John Vander Maas's interest in railroads still continues. While he was employed as a special agent for the $C B E Q$ during World War II, John spent most of his life working in agribusiness. In the meantime, he spends innumerable hours on his "hobby" of gathering railroadiana into a collection that is now coming to the University of Iowa Libraries in annual installments. 